not confirmed by figures of the student enrolments for 1966 to $1967-26$ per cent more students enrolled for courses leading to the council's first degrees in September 1967, compared with the number in 1966. The 1967 figure is 167 per cent more than that for 1965 . The total number of students attending CNAA courses this session is 10,687 , compared with 7,109 at the same time last year.

During 1966-67 the council approved fifty-four courses out of 136 proposed by colleges. Of the courses approved, forty-seven were in science and technology (50 per cent of the number considered) and seven in arts and social studies (17 per cent of the number considered). There are now 173 courses recognized by the council (as at September 1967) covering subjects ranging from aeronautical engineering, agricultural engineering, to textile technology and urban and regional planning. Most are sandwich courses-77 per cent of the courses in science and technology are of this type. One new course, of particular interest to some, is a part-time day and evening course in mathematics at Hatfield College of Technology which is designed especially for mature students.

A useful feature of the CNAA courses is that some are in fields where there are few or no courses in universities; degrees can now be obtained, for example, in building economics, estate management, food science, and photographic technologv. The council also reports that it is considering librarianship and architecture as suitable fields for CNAA degrees. Since the report was written it is undcrstood that a degree in information science has been approved by the council. It is to be offered by the Department of Librarianship at Newcastle College of Commerce as from September 1968. This course is designed primarily to preparc students to work in governmental and industrial information departments.

It is casy to forget that the council also has the power to award higher degrees. During 1966-67, five courses leading to the council's M.Sc. degree were approved, bringing the total number of CNAA postgraduate courses to seven-fifty-three students are enrolled on these. Two of the courses offered are in corrosion science and engineering and in exporimental nuclear physics.

There is a growing number of registrations for the council's rescarch degrees, particularly from candidates in research organizations. The flexibility of the council's arrangements, and the absence of a residential requirement, seen to be proving attractive to many candidates not eligible for higher degrees awarded by universities. The council's Ph.D. degree or M.C.T. (Membership of the College of Technologists) was awarded to twelve students during 1966-67. There are now 317 candidates registered for research degrees.

The council reports continuing good relations with the universities. Many organizations and professional bodies now give CNAA degrees the same recognition as they give to university degrees; for example, the Civil Service in its recruitment policies, and the Burnham committees in their acceptance of graduate qualifications for salary purposes.

It is inevitable that the council's activities are in. separable from the development of the polytechnics. In this connexion the council is continuing its efforts for now types of course, and broader courses combining more than one discipline--courses covering science and technology and social studies, which might be attractive to students who have read arts subjects in the sixth form at school.

\section{Visiting Fellows}

THE Senior Visiting Fellowship scheme of the Science Research Council is undergoing spring cleaning, and the revised regulations are likely to be published in the near future. As it stands at the moment, "the council will make grants to applicants of acknowledged standing to invite senior scientists of distinction in other research schools in this country or abroad to the investigator's institution as senior visiting fellows for a period not exceeding one year to give full-time advice and assistance to the investigator in the field in which the visitors are eminent". The fellowships were designed to bring expert outsiders into individual research projects when specific advice was required, and are therefore included in the research grant scheme. Despite criticism on this score, and suggestions that the visiting fellows should be treated in the same way as research fellows, it is unlikely that the new regulations will alter the grouping of the schemes.

People like Dr N. Kurti of Oxford are enthusiastic about the possibilities of such a scheme, but regret that it has not received more publicity. Another criticism has been raised over the question of pay, because, as the regulations state, "if contribution's to salary or expenses are being made by a senior visiting fellow's parent organization or other body, the charges to the grant will be reduced accordingly". This is thought to be an unfortunate arrangement, particularly for American visitors whose salary is paid on a nine-monthly basis but is considered to cover a year.

Until now, applications for senior visiting fellowships have had to be made on the same complicated forms as those for research grants. But here the criticism seems to have had some effect and the tidying up of the scheme will probably result in a shorter form being produced. It is thought unlikely that the improved scheme will be put before the council itself, which indicates that there is little hope for major changes. Mr L. S. Smith of the SRC has already stated that there will be no increase in the daily allowance for senior visiting fellows. During the year 1965-66, the last year for which figures are available, the council spent $\mathfrak{1 2 , 6 4 5}$ on fifty senior visiting fellowships-a reduction of more than $£ 13,000$ compared with the year before.

\section{Changes at Cold Spring Harbor}

Tre Cold Spring Harbor Laboratory for Quantitative Biology, famous for its annual symposia, its summer courses and for its year-round research in genetics, has recently been strengthened by the appointment of Dr J. D. Watson as director from February 1 of this year. Dr Watson seems to have been persuaded to take on the job, while remaining as Professor of Biochemistry and Molecular Biology at Harvard, by his wish to seo that the laboratory's dramatic improvement from a state of financial and physical bankruptcy would not come to a balt now that Dr John Cairns, the current director, had chosen to concentrate once again 
on research. Dr Cairns, who before his appointment to Cold Spring Harbor had made some elegant autoradiographical studies of DNA duplication, found on his arrival in Cold Spring Harbor an institution entirely without money, some $\$ 80,000$ in debt and with physical plant requiring at least $\$ 1,000,000$ for restoration to a first-class condition. Over the past five years, Cairns has worked heroically; now much of the laboratory has a strikingly pleasant appearance, and the cash reserves are up to $\$ 125,000$. But after five years of this, Cairns naturally wishes to return to his scientific career.

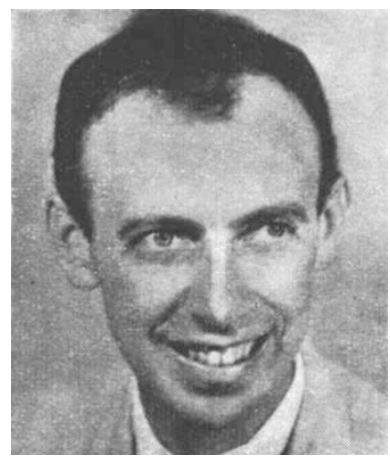

Dr J. D. Watson

The appointment of Dr Watson, already closely connected with the laboratory as a member of the Board of Trustees, and a frequent summer visitor since 1948, should allow a smooth administrative transition. He and Dr Cairns have worked closely together over the past few years, and one of Dr Watson's first aims as director will be to find an endowment for the secure backing of Dr Cairns's position as a staff member. Other immediate objectives will be to find capital funds for a new library to house Cold Spring Harbor's extensive collection of genetic literature, additional summer housing for an enlarged summer course programme and a new laboratory building for expansion of research into the area of molecular biology of higher cells, in particular the multiplication of viruses capable of causing tumours.

\section{Another Hovercraft}

Hovermarine, a small firm based in Southampton, has now produced its first hovereraft, the HM 2 , on licence from Hovercraft Development, Ltd., which handles the patents for the National Research Development Corporation. The design is particularly interest. ing; the hovercraft has submerged sidewalls, so that in motion it looks much like a conventional boat (see picture).

The makers suggest that this sort of craft will be best suited to use in estuaries or rivers, where very large seas are not often experienced. At a speed of $28 \mathrm{knots}$, the craft will comfortably accommodate seas of up to $3 \mathrm{ft}$. in height; in more severe conditions, the company says, the maximum speed attainable will depend on the state of the sea and the amount of discomfort which the passengers are prepared to accept. When hovering, as in the picture, the sidewalls of the craft act as twin keels, giving the craft good directional stability. Shrewdly, Hovermarine says that this will make it possible for operators to pay realistic wage rates to the helmsmen, instead of having to employ skilled pilots. The craft will carry sixty passengers, or sixty-five at full stretch, and costs about $£ 70,000$.

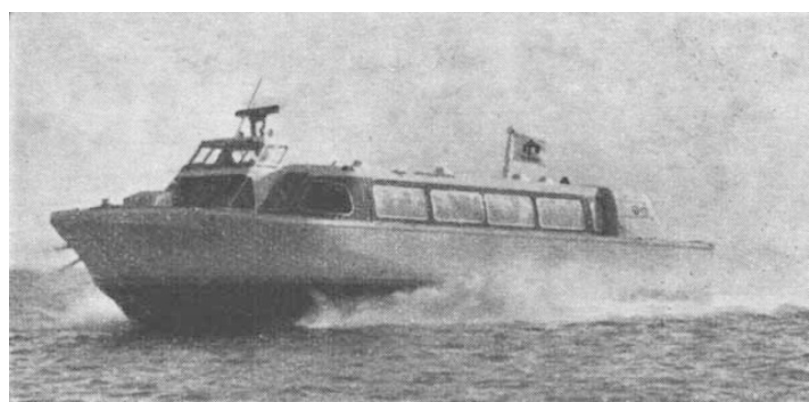

The Hovermarine HM 2 on trials.

In contrast with other hovercraft designs, the Hovermarine HM 2 should be reasonably quiet in operation. It is driven by twin submerged marine screws and not by aircraft-type propellers. Motive power is supplied by two Cummins lightweight diesel engines, and the hover power is supplied by another Cummins engine. The hull is made of glass fibre-reinforced plastics, and the craft can be used from conventional jetties and quays. Hovermarine's own calculations, unsupported as yet by any statistics from operators, show that, at a load factor of 50 per cent and an average speed of 30 knots, operators could make a profit if fares were charged at the rate of $6 d$. a mile. Fares of $9 d$. a mile would produce an annual profit of $£ 25,000$ on the same assumptions, if the craft were depreciated to 10 per cent residual value in 10 years.

\section{Research on Foreign Languages}

IN spite of two British applications to join the European Economic Community, British people remain conspicuously slow at learning foreign languages. There are, however, some signs of impending change, according to the first report of the Committee on Research and Development in Foreign Languages (HMSO, 5s.), which was set up in 1964 under the sponsorship of the Nuffield Foundation, the University Grants Committee, the British Council and what is now the Confederation of British Industry to co-ordinate research and development and to spend a little money-mostly other people's. The chairman is Dr L. Farrer-Brown, a former director of the Nuffield Foundation.

The committee's first experiment was with the teaching of French in primary schools. It has been helped particularly by a pilot scheme begun by the Nuffield Foundation in 1963 which is intended to discover whether a modern language can become a normal part of the primary school curriculum. The report says quite frankly that there are many questions yet to be answered-what is the best starting age ? How much time should be devoted to foreign languages at these tender ages? Are specialists necessary or can ordinary class teachers manage? What is the effect of teaching French on the general performance of the pupils in primary schools? The answers to some of these questions may emerge when the National 